IZA DP No. 972

Transition on the Shop Floor The Restructuring of a Weaving Mill, Hungary 1988-97

J ános Köllõ

December 2003 


\title{
Transition on the Shop Floor - The Restructuring of a Weaving Mill, Hungary 1988-97
}

\author{
János Köllö \\ Institute of Economics Budapest, William Davidson Institute \\ and IZA Bonn
}

\section{Discussion Paper No. 972 \\ December 2003}

\author{
IZA \\ P.O. Box 7240 \\ D-53072 Bonn \\ Germany \\ Tel.: +49-228-3894-0 \\ Fax: +49-228-3894-210 \\ Email: iza@iza.org
}

This Discussion Paper is issued within the framework of IZA's research area Labor Markets in Transition Countries. Any opinions expressed here are those of the author(s) and not those of the institute. Research disseminated by IZA may include views on policy, but the institute itself takes no institutional policy positions.

The Institute for the Study of Labor (IZA) in Bonn is a local and virtual international research center and a place of communication between science, politics and business. IZA is an independent, nonprofit limited liability company (Gesellschaft mit beschränkter Haftung) supported by Deutsche Post World Net. The center is associated with the University of Bonn and offers a stimulating research environment through its research networks, research support, and visitors and doctoral programs. IZA engages in (i) original and internationally competitive research in all fields of labor economics, (ii) development of policy concepts, and (iii) dissemination of research results and concepts to the interested public. The current research program deals with (1) mobility and flexibility of labor, (2) internationalization of labor markets, (3) welfare state and labor market, (4) labor markets in transition countries, (5) the future of labor, (6) evaluation of labor market policies and projects and (7) general labor economics.

IZA Discussion Papers often represent preliminary work and are circulated to encourage discussion. Citation of such a paper should account for its provisional character. A revised version may be available on the IZA website (www.iza.org) or directly from the author. 
IZA Discussion Paper No. 972

December 2003

\section{ABSTRACT \\ Transition on the Shop Floor - The Restructuring of a Weaving Mill, Hungary 1988-97}

While a variety of studies analysed the benign effects of privatisation on firm performance under post-socialist transition using financial data very little is known about how the apparent productivity gains were achieved. This paper follows a weaving mill from 1998 to 1997 on its way of becoming a capitalist enterprise and gives a detailed account of the sources and limits of productivity growth. The data suggests that the factory was not far from the competitive optimum given the size of 'plant and equipment' - efficiency gains were mostly achieved by plant size reduction and asset stripping. The gains from this sort of initial restructuring helped many former state enterprises stay on the market but they did not necessarily indicate high levels of adaptability, capacity to innovate and ability to attract outside investors. In economies with many 'seemingly restructured' privatised enterprises the elimination of the former state sector jobs is likely to continue within the private sector. The process may last for years after privatisation as a legal act had been fully accomplished.

JEL Classification: L2, J31, D21

Keywords: firm behaviour, firm objectives, compensation, transition, Hungary

Corresponding author:

János Köllõ

Institute of Economics

Hungarian Academy of Sciences

Budaörsi út 45

1112 Budapest

Hungary

Email: kollo@econ.core.hu 


\section{INTRODUCTION}

This paper follows a cotton-weaving mill located in western Hungary on its way of becoming a capitalist enterprise. The follow-up starts in 1988 (with some time series dating back to 1972 and even 1957) and lasts until 1997. At the end of the period the weaving plant was succesfully operating as part of a profitable corporation. The paper wants to describe what sorts of actions were required to transform the socialist plant to a capitalist one. Reading the time series backwards can also shed light on how an illfunctioning socialist factory differed from a well-performing capitalist plant.

The decisions on transformation were made at two levels. The goals set by the owners for plant managers were apparently simple and did not change during the period of observation: they were expected to minimise unit labor costs (ULC) taking the equipment at their disposal as given. The outcomes of cost-minimisation under a fixed amount of capital are conditional on the preferences and bargaining power of the workers, managers and the state as was shown by McDonald and Solow (1982) for firms bargaining with employment-aware unions, Carruth and Oswald (1985) for the case of selfish insiders, Svejnar (1982) for the labor-managed firm, and Prasnikar et al. (1994) for the case of three-party bargaining.

The latter model - relevant for the socialist firm operating with a fixed amount of capital assets - predicts that the solution lies east of the demand curve, somewhere at a point similar to $S$ on Figure 1, which turns out to yield low profits and 'too high' wages and employment as the transition begins. Moves from $S$ to the competitive optimum $(E)$ or any feasible points on the demand or contract curves imply cuts of labor input with or without accompanying cuts of wages. Though in the particular case of convex union 
indifference curves there is a scope for Pareto improvement (points in the shaded area north-west of $S$ ) unilateral managerial decisions or 'right to manage' bargaining may lead to other outcomes like $E$ or points between $C$ and $D$ on the demand curve, respectively.

The plant under examination unquestionably moved from $S$ towards $E$, a point where wages were at the disagreement level and labor input close to its optimum. The reduction in ULC, however, was predominantly accounted for by asset stripping and, much lesser degree, increases in sales prices due at least partly to better management, marketing and design In the context of Figure 1 it means that the decisive actions implied the re-scaling of the iso-profit map rather than moves on the original map. (When productivity and prices go up the profits generated at a given level of employment and wages also wind up so each contour represents higher profits). The aim of this paper is to precisely account with these moves and 'parametric shifts' and show how they contributed to the survival of the plant.

Figure 1: Paths leading away from the pre-transiton optimum (S)

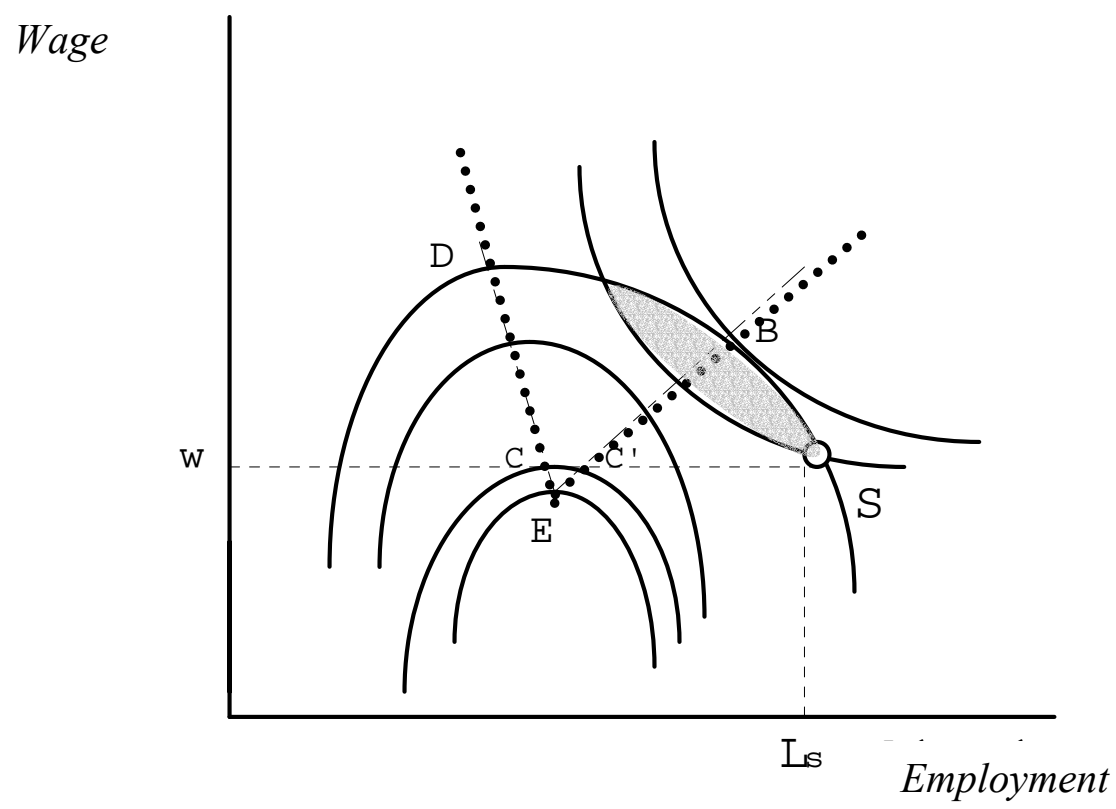


Is there a point in investigating these issues (any issue) by looking at a single case? I believe that a glimpse, or two, inside the black box is highly recommended. We do have evidence of productivity change in privatised and state-owned enterprises from studies using financial data (see for instance Kocenda and Svejnar, 2002 on the Czech Republic, Halpern and Körösi, 2000 on Hungary, and Pinto and Wijnbergen, 1995 on Poland) but these papers tell very little about the sources and limits of productivity growth. The admittedly casual evidence presented here raises two conjectures about the nature of efficiency gains at early stages of the transition.

First, the data suggest that the factory under socialism was not very far from the competitive optimum given the size of plant and equipment. The plant, however, was heavily oversized as it employed many low-productivity workers and low-productivity looms. A major reduction of plant size with little space left for saving jobs by improvements in 'X-efficiency' (as called since the much debated classic by Harvey Leibeinstein, 1966) was an adequate answer to the challenges of competition. This, assuming that the case analysed in the paper is not unique, yields support to the approach of the optimal speed of transition models originating in a study by Aghion and Blanchard (1994). In their benchmark model the state sector is gradually closed without attempts to restructure and job losers move to the private sector via unemployment. The case of the weaving mill fits into this framework in that (to put it simply) no state sector jobs were, or could be, saved by better management or harder work. In the core of the transformation were pure reallocation with one part of the factory closed and the other part changing title. 
Second, initial restructuring wherein large efficiency gains are achieved by asset stripping has implications for the path of transition. Fast-reforming economies produced a multitude of private enterprises by 'title change combined with plant size reduction' at early stages of the transformation. Initial restructuring certainly helped these firms stay on the market but their efficiency gains did not necessarily signal high levels of adaptability, capacity to innovate, or ability to attract outside investors - what the gains actually signaled was changes in the firm's maximand, and the authority of the new owners and managers. In these economies, where past successes are particularly poor predictors of future viability, the elimination of the former state sector jobs is likely to continue within the private sector. This process may take years after privatisation as a legal act had been fully accomplished.

\section{THE PLANT PRIOR TO RESTRUCTURING}

A weaving mill provides unique conditions for the study of transformation on the shop floor. The technology is relatively simple with numerous looms and workers engaged in the same task. Performance is easy to measure and is indeed measured at high frequency. The output lost due to repair, re-tooling, delays in supplies, or low effort are carefully observed and analysed. The required level of worker's effort is dictated by the number of looms per worker and the probability of yarn-break with even latter known ex ante with some precision. I try to benefit from this abundance of information adding results from previous research carried out in the same weaving mill (Köllö, 1982). The data relating to the transition period were collected in 1998-1999 and are available on request. An overview is given in Appendix 2. 
The plant has always belonged to a hierarchically organised textile firm operating a spinning plant, a weaving mill and other departments engaged in the preparatory and finishing stages of manufacturing. About $2 / 3$ of the weavery's output was sold on the market during the period of observation with $1 / 3$ of the cloth processed further in a clothing department producing linen, table-linen, handkerchiefs and - more recently shirts.

Figure 2: Full-capacity output and unit labor cost 1988-96 (log scale)

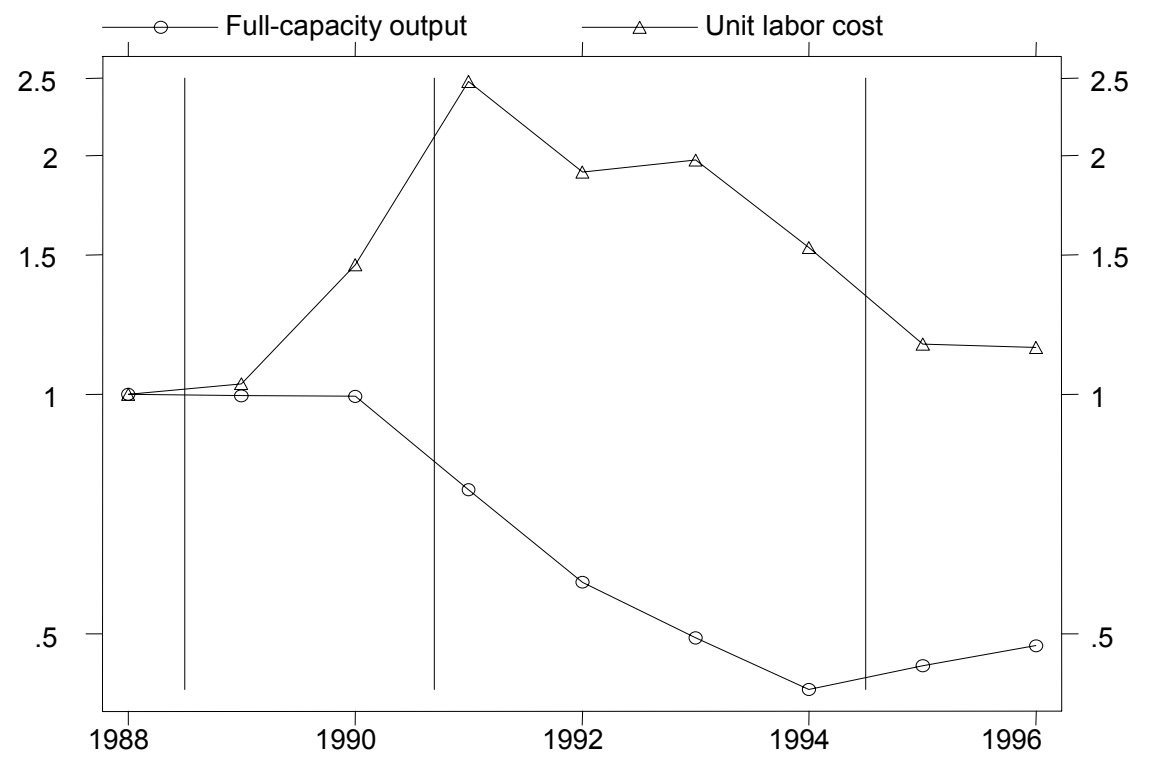

A brief overview of the plant's history during the transition is provided in Figure 2 showing how the size of the plant (measured with potential output under the assumption that all looms operate continuously) and ULC were changing relative to 1988. The vertical lines indicate the dates of changes in ownership. The firm was one of the first Hungarian companies privatised for foreigners in 1989. The new owners left the size of the plant unchanged and tried to earn higher profits by increasing labor input and making major cuts in wages. The failure of this expansive strategy is clearly shown by a dramatic 
rise of ULC in 1989-91 that forced the owners to declare bankruptcy. From late 1991 to 1994 the firm was owned by its main creditor, a commercial bank, undertaking the major steps of restructuring. The size of the weaving plant was halved in this period and ULC fell rapidly. By the end of the period the firm was considered ready for sale and actually sold to a large textile company. The weavery was operated under basically steady conditions thereafter - neither its size nor its technology changed substantially in the late 1990s. ${ }^{1}$

Table 1: Selected indicators of the weaving mill 1988-1991

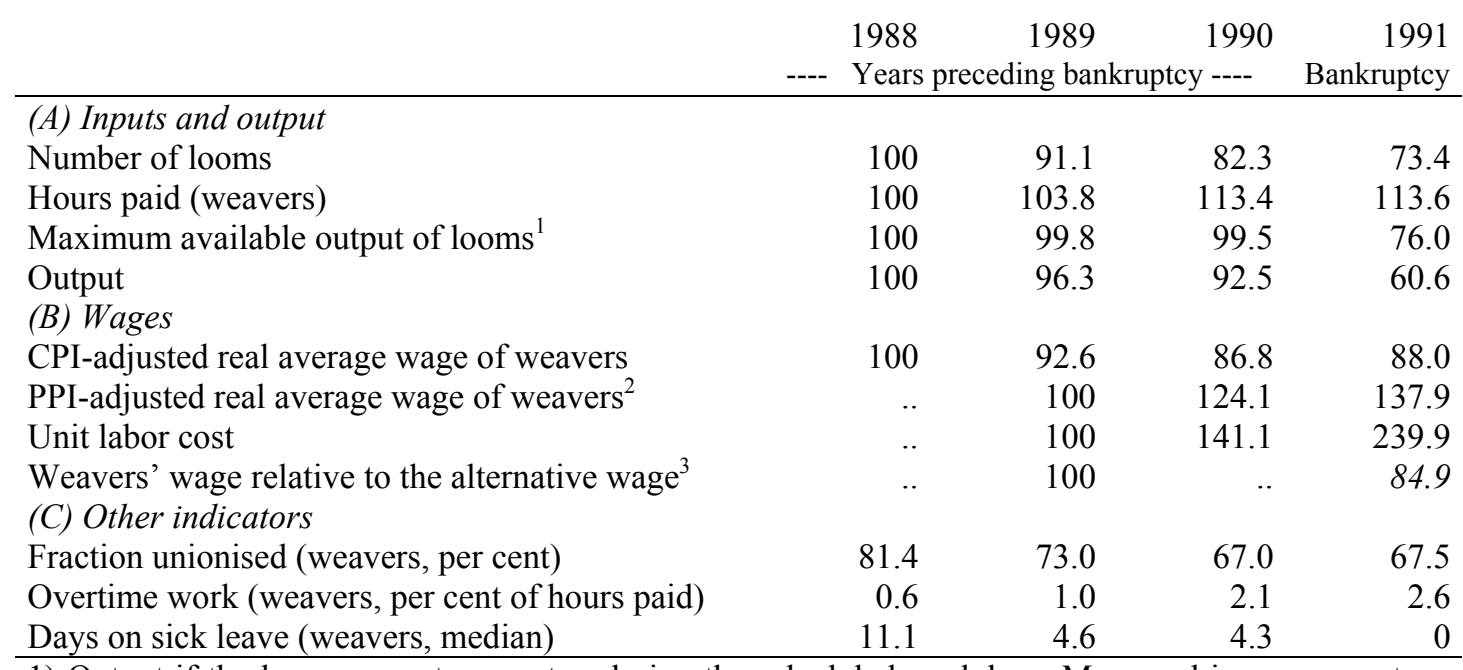

1) Output if the looms operate non-stop during the scheduled workdays. Measured in square meters.

2) The plant's PPI is measured with the price of cloth sold on the market . Not available for 1988.

3) Alternative wage: the mean monthly earnings of female manual workers with primary school background and/or vocational qualification in spinning or weaving, in the macro-region of the firm. Data source: Wage Surveys 1989, 1992. The figure for 1991 is estimate assuming that the alternative wage changed in tandem with the economy-wide average wage in 1991-92.

Before turning to the period of restructuring a more detailed summary is given of how the plant was reformed by its first private owners. As shown in Table 1 the new owners sorted out about 18 per cent of the looms and in the same time expanded the hours of operation by starting a week-end shift comprising twelve-hours workdays on Saturdays

\footnotetext{
${ }^{1}$ A second period of accumulating debts started after 2001 that was explained by fast-rising Hungarian labor costs, appreciation of the Forint, and growing competition on the part of low-wage Asian producers.
} 
and Sundays. This increased the number of weavers from 255 in 1988 to 305 in 1991. (The workers - hired from outside for this particular task - made two shifts a week-end.). As a combined effect, the productive capacity of the plant remained practically unchanged until the year of the bankruptcy. Wages were cut substantially by $12-13$ per cent in real terms and 21 percentage points relative to the weaver's estimated outside option (introduced later). The falling level of unionisation; less days spent on sick leave; and more time worked overtime give further insights of how the bargaining position of workers was deteriorating in this period.

Despite these 'achievements' the firm had to face fast-growing labor costs relative to productivity. The attempt to sell most simple textile products on a market opened for Asian and East-European competitors resulted in falling sales prices and booming ULC. In 1991 the owners (a group of young entrepreneurs nicknamed by the workers as the 'silk scarves') had to declare bankruptcy and move over in favor of the main creditor's trustees.

\section{RESTRUCTURING}

The following sections analyze the firm's decisions over equipment, workers, effort requirements, wages and other factors influencing ULC. The analysis relates to 1991-96 or 1991-97 depending on data availability. At the end of the section the change in ULC is decomposed to show the relative importance of the particular decisions. Throughout the paper the attention is restricted to the weavers and the weaving looms.

\subsection{Selecting the equipment}

The size of the factory was roughly halved in the period of restructuring. This, first of all, meant a reduction of the equipment with the number of looms falling by $53 \%$ between 
1991 and 1997. The selection was non-random and resulted in a major growth of output per loom. Table 2 decomposes productivity change to a compositional effect (the hypothetical change in the average product in case each of the 5 types of looms were operated at its 1991 productivity level); a component capturing the productivity growth within types of looms, and an interactive effect. With $q_{\mathrm{jt}}$ designating productivity and $n_{\mathrm{jt}}$ standing for the share of type $j$ looms at time $t$ the three components are calculated as:

$$
\sum_{j=1}^{5} n_{t j} q_{t j}-\sum_{j=1}^{5} n_{1 j} q_{1 j}=\sum_{j=1}^{5}\left(n_{t j}-n_{1 j}\right) q_{1 j}+\sum_{j=1}^{5}\left(q_{t j}-q_{1 j}\right) n_{1 j}+\sum_{j=1}^{5}\left(q_{t j}-q_{1 j}\right)\left(n_{t j}-n_{1 j}\right)=C_{1}+C_{2}+C_{3}
$$

Table 2: Change of output per weaving loom between 1991 and 1997

\begin{tabular}{lccc} 
& $1991-94$ & $1994-97$ & $1991-97$ \\
\hline Percentage change, of which: & +51.0 & -15.1 & +29.5 \\
Compositional change $\left(C^{1}\right)$ & +33.8 & +1.9 & +39.6 \\
Productivity change $\left(C^{2}\right)$ & +15.7 & -17.1 & -2.9 \\
Interactions $\left(C^{3}\right)$ & +1.5 & +0.0 & -7.1 \\
\hline
\end{tabular}

The decomposition suggests that the growth in output per loom between 1991 and 1997 was entirely accounted for by the selection effect $\left(\mathrm{C}_{1}\right)$ with the productivity of the individual looms $\left(\mathrm{C}_{2}\right)$ increasing in 1991-94 but falling thereafter.

\subsection{Selecting the workers}

Total labor input measured in hours fell by $64.4 \%$ between 1991 and 1996 and the number of weavers (all of them women) dropped from 305 to 97 . The largest cut in employment came in 1991-93 when nearly all workers of foreign citizenship, 83 per cent of the weavers attending outdated mechanical looms on the week-end shifts, and 45 per cent of the rest of the workers were laid off. The criteria applied in screening are first examined by annual probits with the dependent variable set equal to 1 if a weaver on the payroll left by the end of the year, and 0 otherwise. The probability of exit is related to 
age, tenure, marital status, health status, union membership, and the type of loom attended by the weaver (Table 3).

Table 3: Separation from the plant in 1988-1995 - Probits, marginal effects Dependent: Left the plant until the end of the year. Sample: Weavers on the payroll

\begin{tabular}{lccccccccc} 
Year & Age & $\begin{array}{c}\text { Age }^{2} \\
/ 100\end{array}$ & $\begin{array}{c}\text { Min. } \\
\text { prob. } \\
\text { at age }\end{array}$ & \multicolumn{1}{c}{ Tenure } & $\begin{array}{l}\text { Days on } \\
\text { sick } \\
\text { leave } \%\end{array}$ & Married & $\begin{array}{l}\text { Union } \\
\text { member }\end{array}$ & $\begin{array}{c}\text { Old type } \\
\text { loom }\end{array}$ & $\begin{array}{c}\text { Fired or } \\
\text { quitted } \\
\%\end{array}$ \\
\hline 1988 & -.0024 & .0409 &.. & -.0046 & $.0067^{* * *}$ & .0175 & -.0980 & -.0301 & .1942 \\
1989 & .0126 & -.0191 &.. & $-.0131^{* * *}$ & $.0096^{* * *}$ & -.0308 & -.0175 & -.0098 & .2539 \\
1990 & $-.0630^{* * *}$ & $.1078^{* * *}$ & 29.2 & -.0014 & $.0108^{* * *}$ & .1012 & .0136 & -.0561 & .2698 \\
$1991^{1}$ & $-.0939^{* * *}$ & $.1448^{* * *}$ & 31.5 & -.0027 & $.0152^{* * *}$ & $.2049^{* * *}$ & -.0233 & .0833 & .4000 \\
1992 & $-.0801^{* * *}$ & $.1368^{* * *}$ & 29.3 & $-.0176^{* * *}$ & $.0295^{* * *}$ & .1425 & .0918 & $.2045^{* * *}$ & .3680 \\
1993 & $-.0848^{* * *}$ & $.1159^{*}$ & 36.6 & -.0018 & $.0813^{* * *}$ & $.2065^{* * *}$ & .0528 & -.0637 & .1985 \\
1994 & $-.0861^{* * *}$ & $.1197^{* * *}$ & 36.0 & -.0024 & .0037 & $.1409^{* *}$ & .0486 & $.1230^{*}$ & .1182 \\
1995 & -.0014 & .0011 &.. & -.0011 & .0009 & .0055 & -.0113 & .0005 & .1212 \\
\hline
\end{tabular}

Significant at the $* 0.1 * *) 0.05 * * *) 0.01$ level

Most of the estimated effects followed a bell-shaped time path with the strongest influence exerted in 1990-93 - the years of the bankruptcy procedure and the subsequent major down-sizing. In one or several years during this period the workers younger or older than 30, those with short tenures, married women, people coping with health problems, and those working with obsolete equipment were at significantly higher risk of losing their jobs than others. Before and after this period the observed variables had no or had weak effect on the probability of separation. (Union membership had no effect in any year). The age profile of exit changed markedly, with the minimum of the exit probability being at 30 years of age during the redundancies but 36 afterwards.

Table 4 gives a more precise account of the selection criteria during 1990-93 using the discrete time duration model proposed by Jenkins (1995). In this case the units of observation are the annual job spells of the weavers. (New entrants are added to the risk group.) Tenure is measured with dummies allowing for non-monotonous baseline hazard; marital status is interacted with age; citizenship is included, and the model is also 
estimated using the lagged value of the health status variable. This is required because the contemporaneous proportion of days spent on sick leave may be endogenous as long as the workers facing lay-off may go for 'sickness holiday' to search for jobs or have a rest.

Table 4: Discrete time duration model of separation from the plant in the period of downsizing - Logit form, piece-wise baseline hazard, marginal effects and Z-values

\begin{tabular}{lcccc} 
Dependent: Fired/quitted by the end of the year & \multicolumn{2}{c}{$1990-1993$} & \multicolumn{2}{c}{$1991-1993$} \\
\hline Age & -.0852 & 5.00 & -.0902 & 3.07 \\
Age squared (/100) & .1494 & 5.75 & .1597 & 3.65 \\
Tenure $<1$ year ${ }^{1}$ & -.0360 & 0.82 & -.1097 & 0.56 \\
Tenure 5-10 years & -.0891 & 1.98 & -.0858 & 1.13 \\
Tenure 10-15 years & -.0631 & 1.16 & -.0245 & 0.24 \\
Tenure > 15 years & -.2059 & 4.61 & -.2200 & 3.23 \\
Married $\times$ Age 16-34 & .1304 & 2.75 & .1582 & 1.91 \\
Married $\times$ Age 35-50 & -.0215 & 0.37 & -.0314 & 0.36 \\
Days on sick leave (lagged in the second column) $)^{2}$ & .0076 & 4.69 & .0100 & 2.91 \\
Non-Hungarian citizen & .4709 & 9.55 & .6996 & 13.02 \\
Old type loom & .1063 & 2.95 & .1999 & 3.32 \\
Week-end shift & .1415 & 2.45 & .2335 & 2.89 \\
1991 & .0423 & 1.05 &.. &.. \\
1992 & .2352 & 4.60 & .2349 & 3.51 \\
1993 & .0814 & 1.27 & .0922 & 1.12 \\
Number of observations & & 918 & & 546 \\
Pseudo R ${ }^{2}$ & & 0.1617 & & 0.2380 \\
\hline
\end{tabular}

1) Reference: 1-5 years 2) Measured as a percentage of all days in work and sick leave

The results tell more than the cross-section estimates at several points. The effect of tenure appears to be non-monotonous. Workers who spent 15 or more years with the firm had about $20 \%$ lower risk of dismissal while the differences in tenures shorter than that had no effect. Discrimination by marital status was restricted to younger workers - most of them mothers of small children - who had 13\% higher risk compared to their unmarried counterparts. The 'Gästarbeiters', mostly ethnic Hungarians commuting across the border had almost $50 \%$ higher probability of losing their jobs than had the incumbents. The finding that the lagged value of the health variable had similar, even 
slightly stronger, effect than had its contemporaneous value clearly signals the bias against workers coping with illness. The magnitude of the bias is easy to calculate given a one standard deviation band of $13 \%$ of the sick leave variable and a marginal effect of 1 $\%$. Reasons specific to the production process rather than the individual worker (such as having a job in the week-end shift or attending an obsolete loom) increased the probability of exit by $10-15 \%$. While unobserved differences evidently played a role in the selection process, as suggested by the pseudo- $\mathrm{R}^{2}$ values of 0.16 and 0.24 of the logits, the effects of the observables leave no doubt that current productivity was the main consideration during the down-sizing process.

\subsection{Utilizing the looms}

The actual output of a weaving mill lags behind its potential output because of various types of breaks in operations. A part of the potential time frame is devoted to repair, maintenance, and the changing of thread, or wasted for the lack of inputs $\left(\mathrm{t}^{\mathrm{S}}\right)$. Another part is lost during the seconds or minutes elapsing between yarn-breaks and the weaver's intervention $\left(\mathrm{t}^{\mathrm{W}}\right)$. An overview of how these breaks were changing over time is given in Table 5. Appendix 1 explains how $t^{\mathrm{W}}$ was estimated.

The time lost due to repair, maintenance, re-tooling and lack of inputs $\left(\mathrm{t}^{\mathrm{S}}\right)$ had a historically increasing trend starting from about 5 per cent in 1957-70, just above 10 per cent in 1971-78 and 1988, 20 per cent during the restructuring period, and 25 per cent after the plant's restructuring. 
Table 5: Output lost due to breaks of different kind 1957-97

\begin{tabular}{ccc} 
Year & $\mathrm{t}^{\mathrm{s}}$ & $\mathrm{t}^{\mathrm{W}}$ \\
\hline $1957-60$ & 6.1 &. \\
$1961-65$ & 4.8 &. \\
$1966-70$ & 5.4 &. \\
1971 & 10.0 & 21.6 \\
1972 & 10.9 & 20.2 \\
1973 & 9.6 & 20.0 \\
1974 & 11.9 & 18.4 \\
1975 & 12.9 & 18.9 \\
1976 & 12.1 & 16.4 \\
1977 & 12.3 & 14.7 \\
$\ldots$ &. &. \\
1988 & 10.7 & 12.3 \\
$\ldots$ &. &. \\
1991 & 16.6 & 22.0 \\
1992 & 19.8 & 15.8 \\
1993 & 25.0 & 16.3 \\
1994 & 17.6 & 9.7 \\
1995 & 21.3 & 11.2 \\
1996 & 24.9 & 12.7 \\
1997 & 29.0 & 11.6 \\
\hline
\end{tabular}

This rise was strongly affected by the growth of quasi-idleness required to adjust the looms to changing orders. A weaving plant inevitably loses time for changing cylinders and yarn - the smaller and more variable the batches the more time is 'wasted' for this. The curve in Figure 3 depicts how two major components within $\mathrm{t}^{\mathrm{S}}$ were changing between 1991 and 1997. The time loss explained by changing thread and cylinder was rising rapidly after 1994 as the firm shifted to smaller batches and a wider assortment of clothes. The losses explained by unavailable inputs such as absent workers and undelivered thread or compartments were at low levels in 1991 when production plummeted during the bankruptcy procedure, and jumped high during the period of down-sizing and relocation bringing about disturbances in co-operation. In 1994-97 the time lost for shortages stayed around $6 \%$ level. The patterns of change are supportive of Kornai's (1980) notions of the 'supply constrained' socialist versus the 'demand constrained' capitalist firms. 
Figure 3: Time lost for two types of reasons, 1991-1997

Per cent of the total time base

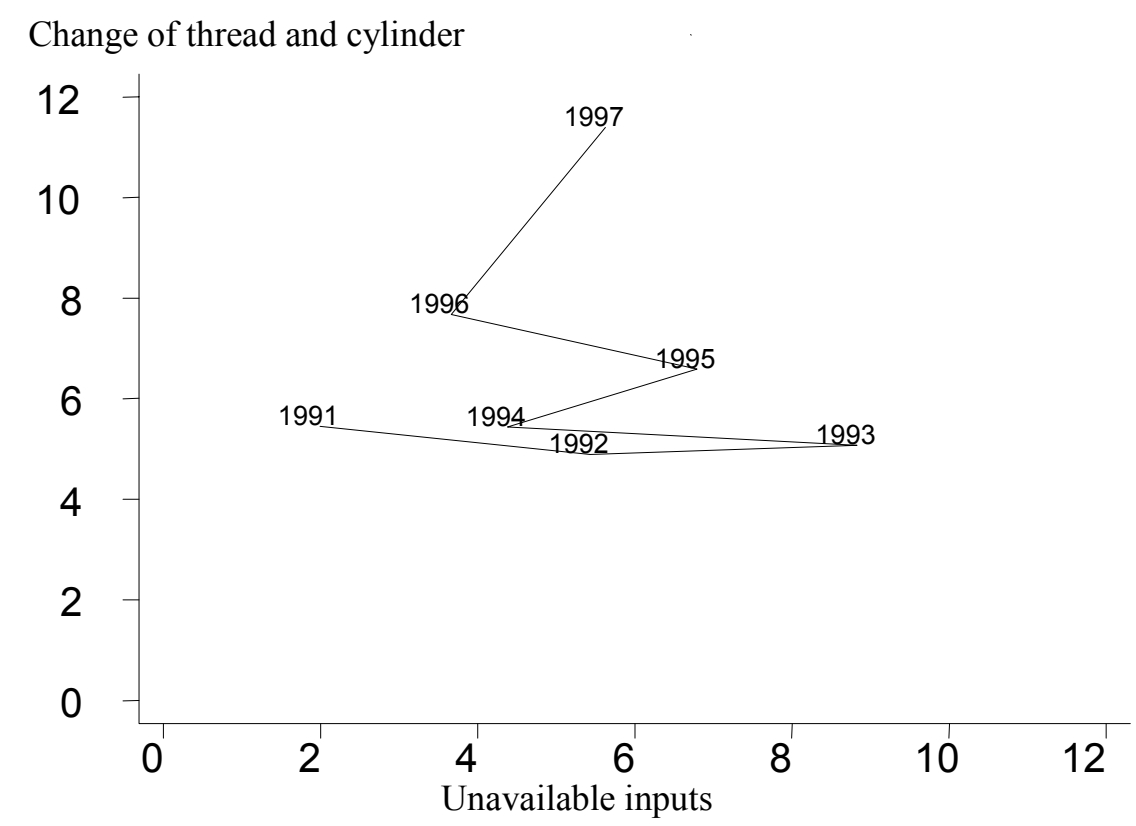

Turning back to Table 5 we find that the time lost because of delays in the weavers' interventions $\left(\mathrm{t}^{\mathrm{W}}\right)$ followed a historically decreasing trend with its average value being 19 per cent in 1971-77 and 13 per cent in 1991-97. However, $\mathrm{t}^{\mathrm{W}}$ was at a 12.3 per cent level already in 1988 and did not improve later. This is basically explained by the limits of increasing work effort as discussed in the next section.

\subsection{Increasing work effort}

The required level of effort on the part of a weaver is determined by the predicted probability of yarn-break known ex ante with some precision. There is an optimal number of interventions per hour that fully exhausts the weaver's worktime on the one hand, and ensures that no loom is left unattended, on the other.

The trade-off between effort and productivity (the ratio of actual to potential output of the looms under a weaver's supervision) is illustrated by Figure 4. The sketch shows 
how the potential and actual yields of the looms are expected to grow as the productive capacity under a weaver's control is extended. The size of the capacity attended by the weaver (horizontal axis) is measured with the potential output of the looms under her control that also implies a particular frequency of yarn-breaks and a particular level of required effort.

Figure 4: Actual and potential ouput per worker

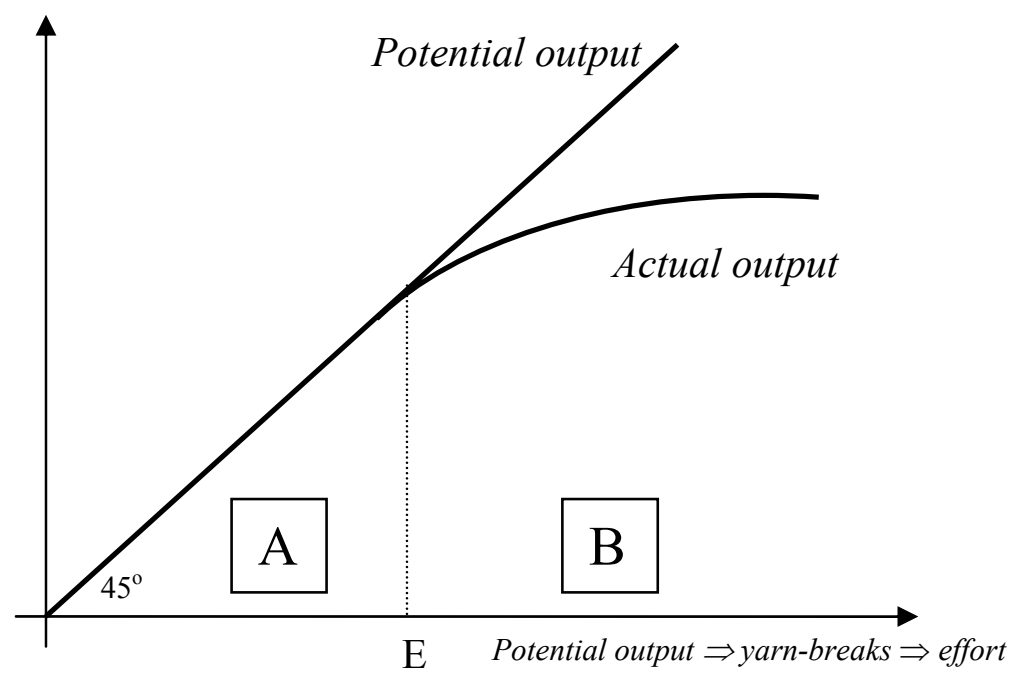

When the firm is in regime $A$ the increases in the potential output bring about proportional increases in the actual output provided that the workers are properly monitored and the required level of effort is enforced. At the optimal level of required effort $(E)$ output per worker is the highest among all effort standards ensuring the full utilization of the equipment. Beyond this point, in regime $B$, any further increase in the prescribed workload reduces the ratio of actual to potential output and adds to ULC. Setting effort requirements stricter than $E$ is irrational since the plant would be better off by choosing $E$ and hiring additional workers to attend the looms left without supervision. 
The optimal effort requirement is not known with certainty - it is approximated with the aid of preparatory calculations, learning from past experience, and trial-and-error. As a benchmark the firm adapted an internationally acknowledged standard of 41 interventions per hour. As shown in Figure 5 the required level was set at 20-25 interventions in 1968-76 and above 41 in all years but one between 1991 and 1997.

Figure 5: Interventions per hour. 1968-76 and 1991-97 annual means

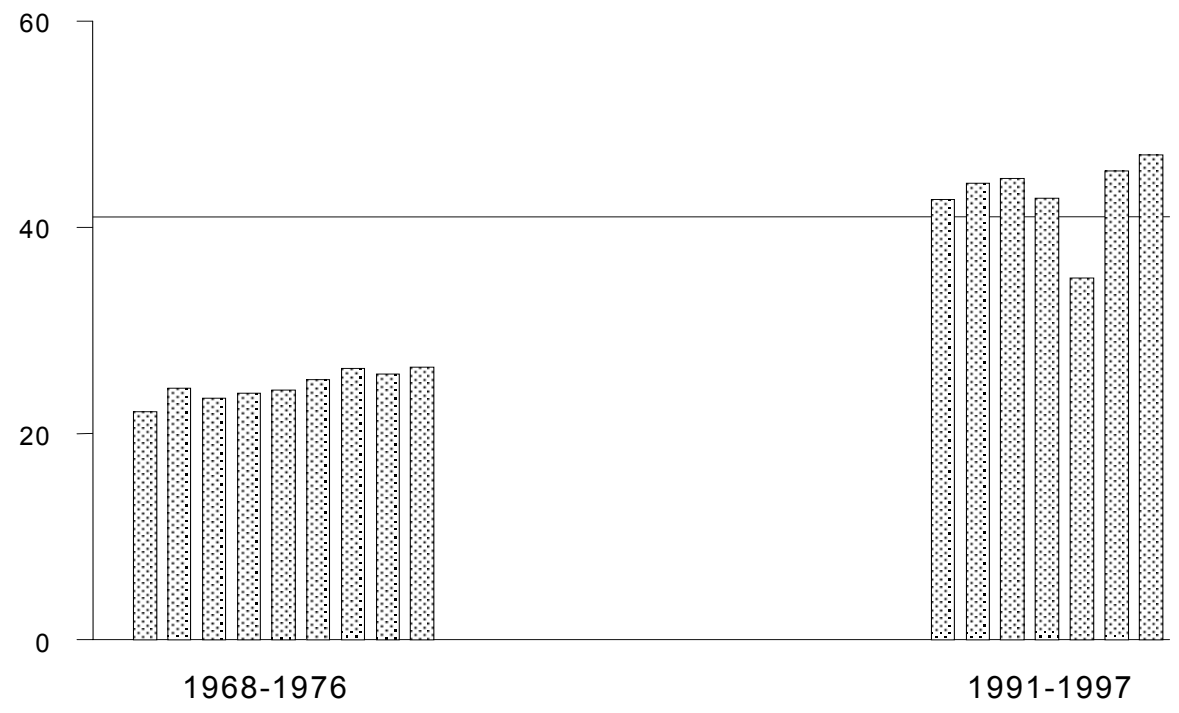

Why was the effort requirement set deep below the acknowledged standard under socialism? The reasons were rooted in the logic of the production process under supply constraints. As the output target was high relative to the number of auxiliary and repair workers (among others) weavers were expected to perform a series of supplementary tasks including material handling, search for compartments and thread, and the fixing of their looms. During the transition, as the plant re-established a clear division of tasks the weavers could devote their entire time frame to their own job and the firm could set the 
effort requirements closer to the standard. This also implies that the actual workload did not grow as fast as suggested by the doubling of the number of interventions.

While the growth in worker effort is difficult to assess it seems that by setting the level at 42-45 interventions an hour the plant shifted to regime $B$. This can be demonstrated by estimating the linkage between changes of the required level of effort and changes of productivity. Data on this are available for 5 types of looms and 75 months between 1991 and 1997. Using this panel equation (2) relates the productivity of loom type $i$ at time $t\left(N E T_{\mathrm{it}}\right)$ to the required level of effort $\left(e_{\mathrm{it}}^{*}\right)$; time interval dummies capturing the effort-unrelated improvements in productivity $(T)$; type-of-loom fixed effects $\left(c_{i}\right)$; and an error term $u_{\mathrm{it}}$. The NET productivity measure is defined as the ratio of actual output to the maximum available output under the actual duration of operation (time frame less breaks for reasons other than delays in the weaver's intervention, as described in detail in Appendix 1). In the equation $e^{*}$ it is measured relative to the 41 interventions/hour standard. In regime $B$ the key coefficient $\beta_{1}$ is expected to be negative.

$$
\ln N E T_{i t}=\beta_{1} \ln e_{t}^{*}+\beta_{2} T+c_{i}+u_{i t}
$$

The estimate of $\beta_{1}$ from the fixed effects regression is -0.12 suggesting that the fluctuations of $e^{*}$ within its two standard deviations band resulted up to 4.7 percentage points shifts of opposite direction in productivity (Table 6$)^{2}$. The fixed effects coefficient may be attenuated by an omitted variable bias, however. The actual effort requirements (e) are dictated by the actual frequency of yarn-breaks - this may deviate from $e^{*}$ due to unforeseen deviations in thread quality, humidity, or other factors affecting the probability that a loom stops. Denoting the deviations with $\mathcal{E}$ we have $e_{i t}=e^{*}{ }_{i t}+\varepsilon_{i t}$ in a

\footnotetext{
${ }^{2}$ The equality of the fixed and random effects coefficients is accepted at a 0.98 level in the Hausman-test.
} 
structural equation and supposedly $\operatorname{Cov}\left(e^{*} \varepsilon\right)<0$. When, for instance, thread quality turns out to be poor in practice, and the residual productivity $\beta_{1} \varepsilon_{i t}+u_{i t}$ falls the management may be tempted to lower $e^{*}$ in order to maintain high levels of NET. ${ }^{3}$

Table 6: Productivity and effort 1991-97 - Estimates of equation (2) and system (3) Dependent variable: ratio of actual to potential output $(\log )$

\begin{tabular}{lll}
\hline Model: & Fixed effects & Multiple indicators IV \\
Instrument for effort & -- & No. of looms attended \\
\hline Required effort (log) & $-0.1158(0.0430)^{* * *}$ & $-0.2688(0.1625)^{*}$ \\
Restructuring (1992-94) & $0.0756(0.0228)^{* * *}$ & $0.0764(0.0232)^{* * *}$ \\
Post-restructuring (1995-97) & $0.1128(0.0233)^{* * *}$ & $0.1221(0.0256)^{* * *}$ \\
Constant & 4.883 & 5.6009 \\
$\mathrm{R}^{2}$ within / between / overall & $0.0768 / 0.2480 / 0.0840$ & $0.0457 / 0.2596 / 0.0695$ \\
Observations / groups / max months & $357 / 5 / 74$ & $357 / 5 / 74$ \\
\hline Standard errors in brackets. Significant at the $\left.\left.{ }^{*}\right) 0.1^{* * *}\right) 0.01$ level
\end{tabular}

While the fixed effects model assumes that $e^{*}{ }_{i t}$ is a precise measure of $e_{i t}$, in an alternative specification tested the assumption is that the level of required effort is unobserved. Instead of the true level we have observations on two correlated indicators: $e^{*}$ and the number of looms attended by a weaver $n^{*}$. This is analogous to the problem addressed in the multiple indicators IV models (Woolridge, 2002, 105-106) in that we have a structural equation with $e_{\text {it }}$ being unobserved and two indicators correlated with $e_{\text {it. }}$. If the indicators are redundant in the structural equation (being proxies they evidently are), and $\delta_{1} \neq 0, \rho_{1} \neq 0$, and $\operatorname{Cov}\left(v_{1} v_{2}\right)=0$ hold any of the two proxies can be used as an instrument for the other to get consistent estimate of $\beta_{1}$.

$$
\begin{aligned}
& \ln N E T_{i t}=\beta_{1} \ln e_{i t}+\beta_{2} T+c_{i}+u_{i t} \\
& e_{i t}^{*}=\delta_{0}+\delta_{1} e_{i t}+v_{1} \\
& n_{i t}^{*}=\rho_{0}+\rho_{1} e_{i t}+v_{2}
\end{aligned}
$$

\footnotetext{
${ }^{3} \mathrm{We}$ can reasonably assume that the adjustment process is fast enough not to produce lagged effects in a
} 
The assumption of uncorrelated errors states that any correlation between the proxies arises through their common dependence on $e$. This is not necessarily met in our case because the managers' misperceptions of $e$ may result in positively correlated errors. Therefore, while the estimate of $\beta_{1}$ in the fixed effects model is lower-bound the one from the IV is predictably upper-bound. Estimating (2) using $n^{*}$ as an instrument for $e^{*}$ yields a coefficient of $\beta_{1}=-0.27$ (significant at the 0.09 level) that implies 5.7 percentage points productivity differential at the margins of the two standard deviations band of $e^{*}$. There is a minor difference of the expected sign between the fixed effects and the IV coefficients but their suggestions are similar: the plant arrived at a margin where further increases in the prescribed workload resulted in falling levels of capacity utilization.

\subsection{Decreasing wages}

The decline in weavers' real wages started, but did not come to an end, under the first private owners of the enterprise. The CPI-adjusted average real hourly wage fell from 64.8 Ft in 1988 to $53.4 \mathrm{Ft}$ in 1991 and, following a short period or recovery, a low of 44.2 Ft in 1996. A loss of similar magnitude can be observed when the weaver's wages are compared to their outside option. This was calculated as the regional mean wage of female workers employed as unskilled/semi-skilled laborers or spinners/weavers. This choice is justified by the observation that the overwhelming majority of the weavers who quit their employers are hired for low-skilled jobs (Köllö, 1982). ${ }^{4}$ Data on outside wages were available in 1989 and each year in 1992-96. In 1989 the plant's weavers earned 146 $\%$ of the outside option - this comprised returns to being employed at a large, 'politically important' enterprise, reflected the impact of a wage grid where weaving was considered 
a skilled job, and the system of incentives discussed below. Privatisation evaporated a large part of the firm-specific earnings advantage that fell to $115 \%$ in 1992 and $112 \%$ in 1996. Given that the wage advantage of workers employed in multiple shifts over the average worker amounted to 20 per cent in the region these latter percentages hint at earnings levels at (or even below) the alternative wage. ${ }^{5}$

Figure 6: Real hourly wages and relative monthly earnings of weavers 1988-96 Annual means and one standard deviation bands, log sacales

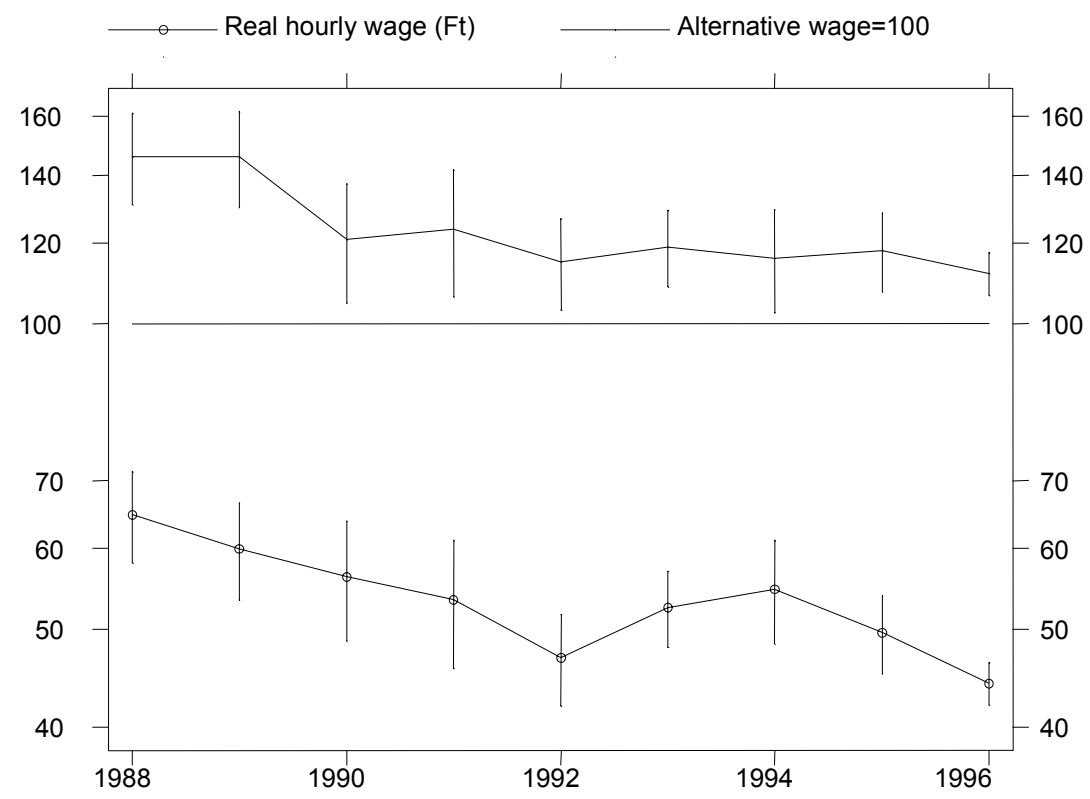

Not only the level of wages but the way wages could be earned did change substantially during the transition. Under socialism incentives were based on the firmspecific earnings rents, strong seniority (delayed payment), and a linear piece-rate system without setting lower limits to effort. This was consistent with the firm's incentives to maximize output rather than efficiency and its ability to draw rents. The system of

\footnotetext{
4 'Regional' stands for the NUTS-2 region of the enterprise and 'wages' are meant to be gross monthly earnings since hourly data are not available in the Wage Survey used to calculate the alternative wage.
} 
payment by results was replaced by fixed hourly rates as early as 1990 while managers put more effort in monitoring the workers and enforcing a satisfactory level of effort.

The elimination of the piece-rate scheme was stimulated by growing difficulties in finding reliable indicators for effort. As the firm moved to smaller batches the quantity produced became too noisy proxy to rely on - a problem that often undermines the practice of payment by results as discussed in Milgrom and Roberts (1999). Consistent with the shift to fixed wages the linkages between age, tenure and pay were eliminated as shown by the earnings functions of Table 7.

Table 7: Real hourly wage equations 1988-95

Dependent: Log hourly wage at 1988 consumer prices

Dependent of the selection probit: was employed by the end of the year

\begin{tabular}{lcccccccc} 
& 1988 & 1989 & 1990 & 1991 & 1992 & 1993 & 1994 & 1995 \\
\hline Age & $.0409^{* * *}$ & $.0513^{* * *}$ & $.0434^{* * *}$ & $.0665^{* * *}$ & $.0441^{* * *}$ & .0081 & $.0233^{* *}$ & $.0180^{*}$ \\
Age squared $(/ 100)$ & $-.0569^{* * *}$ & $-.0717^{* * *}$ & $-.0646^{* * *}$ & $-.0993^{* * *}$ & $-.0706^{* * *}$ & -.0000 & $-.0277^{*}$ & -.0206 \\
Tenure & $.0076^{* * *}$ & $.0055^{* * *}$ & $.0087^{* * *}$ & $.0098^{* * *}$ & $.0081^{* * *}$ & .0012 & $.0027^{*}$ & .0016 \\
Old type loom & .0119 & .0001 & $-.1252^{* * *}$ & $-.0873^{* * *}$ & $-.1497^{* * *}$ & $-.1431^{* * *}$ & $-.1264^{* * *}$ & $-.0951^{* * *}$ \\
Week-end shift & - & - & $.4869^{* * *}$ & $.3001^{* * *}$ & $.2615^{* * *}$ & $.2737^{* * *}$ & $.3313^{* * *}$ & $.2260^{* * *}$ \\
New entrant & $-.3025^{* * *}$ & $-.1374^{* * *}$ & $-.1272^{* * *}$ & $-.0576^{* *}$ & $.0995^{*}$ & .0433 & .0266 & -.0854 \\
Constant & 3.4121 & 3.2130 & 3.4779 & $2.7690^{*}$ & 3.0882 & 3.6647 & 3.4280 & 3.4879 \\
$\lambda$ & $.0612^{* *}$ & -.0191 & -.0500 & $.1309^{* * *}$ & .0041 & $.0853^{* * *}$ & $.1030^{* * *}$ & $-.0760^{* * *}$ \\
Nobs & 232 & 207 & 307 & 305 & 193 & 131 & 110 & 99 \\
\hline
\end{tabular}

The wage equation is estimated for weavers employed by the end of the year with the selection equation including age, age squared, dummy for tenure longer than 15 years, marital status, days on sick leave, and citizenship. Pro memo items (exit and entry as per cent of the weavers on the year's payroll):

$\begin{array}{lllllllll}\text { Exit } & 19.4 & 25.4 & 26.9 & 40.0 & 36.9 & 19.9 & 11.8 & 12.2 \\ \text { Entry } & 11.6 & 23.8 & 39.7 & 24.6 & 5.2 & 6.9 & 4.6 & 2.0\end{array}$

Significant at the $*) 0.1 * *) 0.05 * * *) 0.01$ level

Similarly to the case of effort requirements it seems that the firm has reached the limits of further savings on wages. This is indicated by the wage differential between new entrants and incumbent workers in Table 7. While until 1991 the plant was able to hire workers at

\footnotetext{
${ }^{5}$ This regression-based approximative calculation relies on the 1998 wave of the Wage Survey where shift work was distinguished with a dummy variable. No similar information was available prior to 1998.
} 
wages deep below the incumbent's earnings the gap completely disappeared by 1992 as the firm-specific earnings rents were eliminated.

Figure 7: Time lost for the shortages of weavers 1968-78 and 1988-97

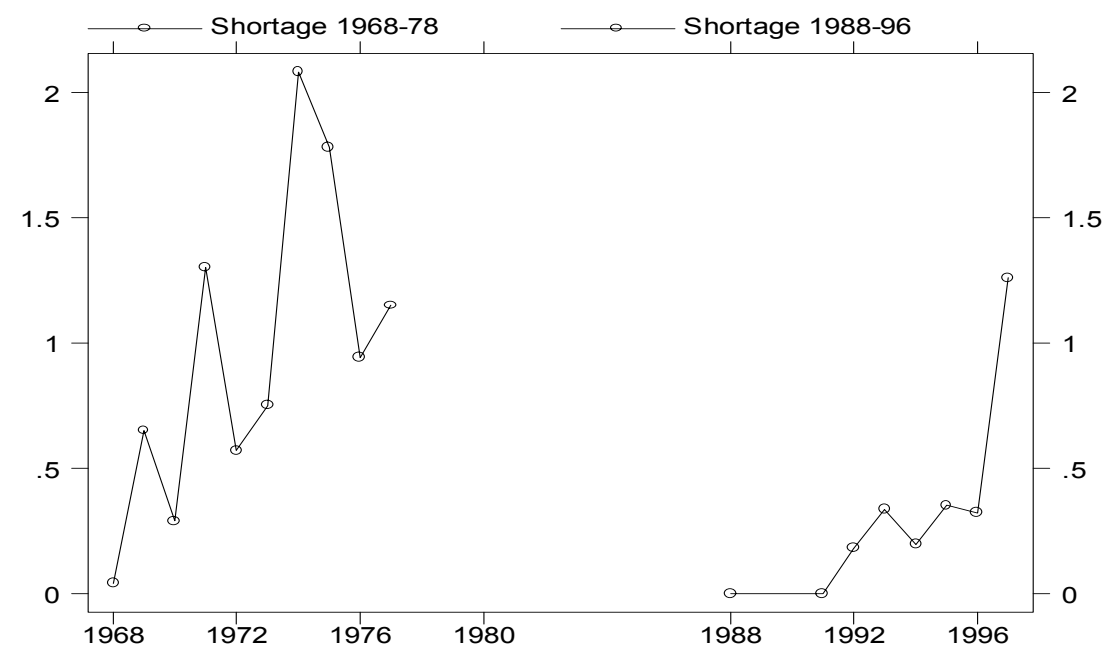

The proximity of the limits is also shown by the time wasted for the lack of weavers. What the plant records under this heading is how long were some looms entirely withdrawn from production thus it is part of $\mathrm{t}^{\mathrm{S}}$ not $\mathrm{t}^{\mathrm{W}}$. As shown in Figure 7 no time was lost for this reason at all in 1988 and 1991 but starting from the early 1990s labor shortages reached the levels characteristic of the early 1970s.

\subsection{Residual effects}

There are important actions affecting ULC including improvements in marketing, design, and organization, which are difficult or impossible to observe. The only way to learn about them is to try to measure their combined influence on ULC as a residual effect.

(4) $\Delta \ln \frac{w L}{p Q}=\Delta \ln \frac{w}{w^{*}}+\Delta \ln \frac{w^{*}}{p^{C}}+\Delta \ln \frac{p^{C}}{p^{T}}+\Delta \ln \frac{p^{T}}{p}+\Delta \ln \frac{Q}{Q^{\max }}+\Delta \ln \frac{Q^{\max }}{L}$ 
At this aim formula (4) decomposes the change in ULC to factors that definitely do not reflect improvements in corporate management and others, which at least potentially do. Denoting wages and employment with $w$ and $L$, the alternative wage with $w^{*}$, output with $Q$, and prices with $p^{C}$ (consumer prices), $p^{T}$ (sales prices in textiles) and $p$ (sales prices of the firm) equation (4) results in six components. Proceeding from the left to the right the components capture the change in the firm-specific earnings rent, change in the alternative real wage, the wedge between consumer prices and the textile industry's sales prices, the wedge between the firm's and the industry's sales prices, capacity utilization, and the change in the potential productivity of labor. The second and the third components are given for the firm while the first and the last need no innovative actions on the part of the management. However, both the growth of relative prices $\left(p / p^{\mathrm{T}}\right)$ and the improvements in capacity utilization $\left(Q / Q^{\max }\right)$ can be attributed to managerial effort to a large extent.

Table 8: The components of log change in unit labor costs, 1991-96

\begin{tabular}{lr}
\hline Alternative CPI-adjusted real wage & -0.088 \\
Firm specific earnings rent & -0.102 \\
& \\
Wedge between the CPI and the textiles industry's PPI & 0.316 \\
Wedge between the firm's PPI and the textile industry's PPI & -0.294 \\
& \\
Improvement in capacity utilization & -0.015 \\
Improvement in potential output/worker & -0.600 \\
Total log change in ULC & -0.772 \\
\hline ULC: unit labor cost, CPI: consumer price index, PPI: producer price index
\end{tabular}

As shown in Table 8 the wedge between consumer and producer prices increased the plant's ULC by almost $1 / 3$ that was only partly offset by the fall of the alternative real wage. Starting from this augmented level the plant's ULC was roughly halved by actions under the management's control. The growth in potential labor productivity (down-sizing 
combined with asset stripping) had far the largest contribution to this - about six times as important as the cutting of wages and twice as large as the contribution of price increases.

Arguably, the increase in the firm's relative sales price gives an upper-bound estimate of returns to better management, design and organization. First, as was discussed earlier, there is a trade-off between product quality and capacity utilization. The failure to improve the latter should be accounted as a cost paid for better quality and the timely delivery of smaller and smaller batches - this deductible reduces the net return to managerial efforts. Second, the price improvements themselves contained a compositional effect as the firm stopped producing some low-priced products such as bed-linen and napkins formerly delivered for state orders. However, even if we attribute the entire change in relative prices and natural productivity to innovation its contribution to the total decrease of ULC amounts to only about $30 \%$ as opposed to $60 \%$ gained by the selection of the inherited equipment and $10 \%$ explained by wage cuts - neither requiring sophisticated managerial skills.

\section{LESSONS FOR RESEARCH}

The way in which the weaving mill was transformed was by no means unique - there is sufficient anecdotal evidence of similar cases highlighting the importance of the inherited assets used as a source of rents either by 'skimming the cream' of the equipment or using it as a flexibility reserve. In a case study of an engine plant 1990-97 Károly Fazekas (Fazekas and Köllö, 1998) reported an output loss over 90\%, employment cuts exceeding $50 \%$, and virtually no change in the size of 'plant and equipment'. The inherited pool of machines was used as a buffer in meeting orders for small batches. Centrum, once Hungary's largest chain of department stores cut its real turnover by $82 \%$, employment 
by $60 \%$, and the total space of shops by only $18 \%$ between 1988 and 1997 , creating a unique abundance of assets relative to current inputs and turnover (Centrum, 1988).

In evaluating the macro-economic importance of a multitude of similar cases one has to consider, first of all, that the share of economic units surviving from socialism may have been significantly higher than suggested by the financial datasets. There is no way to prove this statement but there are pieces of statistical evidence hinting at severe bias in the firm-level data sets customarily used to assess the pace of change.

A survey of the EBRD conducted in 2000 (Commander and Köllö, 2002), which contained detailed questions on firm histories revealed that $44 \%$ of the private enterprises in the random sample existed as a state firm or part of a state firm in 1989 and had an equipment older than 10 years, that is, inherited from socialism. A survey of inflows to unemployment conducted by Hungary's National Labor Center (NLC) in 1994 suggested that $43.9 \%$ of the job losers worked in the same enterprise as in 1989 while the firm-level observations of the Wage Survey from the same year suggested a share of only $16.5 \%{ }^{6}$ It might also be mentioned that the Firm analysed in this paper appeared six times as a dying and/or newly established enterprise in the firm-level data sets whenever its owners changed between 1988 and 1995 - while the company was continuously operating in its century-old building.

There is scarce evidence suggesting that the surviving units basically relied on their inherited assets without major investment and modernization. Table 9 presents data from a panel of firms surviving 1990-94 without changing ID. Less than 1/10 of these firms reported investments in 1992-94, more than half of them had unused capacities, and

\footnotetext{
${ }^{6}$ Author's calculation using the original data sets.
} 
the majority of them maintained the underutilized assets - waiting for better days or using them as reserves in the way discussed earlier.

Table 9: Selected indicators of continuos firms 1990-94, \%

Sample: Firms bearing the same ID in 1990 and 1994

\begin{tabular}{cccc}
\hline & $\begin{array}{c}\text { Activates new capacity } \\
\text { within 6 months }\end{array}$ & Has underutilized capacity & $\begin{array}{c}\text { Underutilized capacities not } \\
\text { sold / sorted out }\end{array}$ \\
\hline & & All firms (N=928) & \\
1992 & 8.3 & 55.5 & 61.1 \\
1993 & 8.5 & 57.5 & 70.5 \\
1994 & 8.3 & 54.9 & 72.1 \\
& & Manufacturing (N=257) & \\
1992 & 9.8 & 55.5 & 73.5 \\
1993 & 7.3 & 57.2 & 80.4 \\
1994 & 6.6 & 55.4 & 78.5 \\
\hline
\end{tabular}

Source: Author's calculations using the 1992-94 August-December waves of the Short-term Labor Market Prognosis Survey of the Hungarian National Labor Center

A similar picture emerges from the EBRD survey suggesting that $47 \%$ of the private firms originating in socialist times did not introduce new product in 1997-2000 and 39\% did not upgrade any of its existing product lines. While as much as $3 / 4$ of these firms were profitable in 2000 they had inferior performance in terms of job creation with $43.5 \%$ of them destroying jobs in $1997-2000$ as opposed to only $25.6 \%$ with other private firms. ${ }^{7}$

These data draw the attention to a kind of heterogeneity within the post-transition population of firms that cannot be captured by indicators like ownership or current profitability. Many of the currently successful private firms came into being by the sort of initial restructuring described in this case study. They are on the market but the decision on their survival is yet to come when their assets need to be replaced and the resulting capital costs should be covered from their intakes. Most probably, many of these firms has yet approached the limits in wage cuts and effort requirements as was the case in the

\footnotetext{
${ }^{7}$ The data quoted here partly appear in Commander and Köllö (2002) but some of them result from new calculations using the original data set.
} 
weaving plant. Since the past successes of the firms relied on actions that did not require innovation, technological renewal, high levels of adaptability, or outstanding managerial skills their future remains uncertain and quite a few of them will predictably fail when new challenges like the speed-up of wage convergence and growing competitive pressures after the EU accession are to responded.

Acknowledgement. The data for this case study were collected in cooperation with Károly Fazekas in a joint project supported by the SOCO program of the Institut für die Wissenschaften vom Menschen, Vienna. This paper was written in 2003 during a scholarship at the William Davidson Institute at the University of Michigan, Ann Arbor. I am grateful to the WDI for providing support and an inspiring and helpful environment. I am indebted to the employees of the firm analysed in the paper for their cooperation.

\section{References}

Aghion, P. and O.J. Blanchard (1993): On the speed of transition in Central Europe, MIT 1993, EBRD, 1994

Carruth, A. and A. Oswald (1987): On union preferences and labour market models: insiders and outsiders, The Economic Journal, June, pp. 431-445

Centrum (1998): Report by Centrum Department Stores Directorate of Controlling, Népszabadság, 1 August, p27

Commander and Köllö (2001): The changing demand for skills - Evidence from the transition, Presented at the EBRD Annual meeting, December 12-13, London 
Fazekas, K. and J. Köllő (1998): Plant Size Reduction, Productivity Growth and the Employment Relationship. Case Studies of Two Hungarian Industrial Plants, downloadable at http://www.iwm.ac.at/Soco

Halpern, L. and G. Körösi (2000): Efficiency and market share in the Hungarian corporate sector, WDI Working Paper No. 333

Kocenda, E. and J. Svejnar (2002): The effect of ownership forms and concentration on firm performance after large scale privatization, WDI Working Paper No. 471a

Kornai, J. (1980): The economics of shortage, North Holland, Amsterdam

Köllő, J. (1982): Wage bargaining and internal labor market in a cotton weaving mill (in Hungarian), in: P. Galasi (ed.): The labor market in Hungary (in Hungarian), KJK, Budapest

Leibeinstein, Harvey (1966): “Allocative efficiency versus ‘X-efficiency””, American Economic Review, Vol 56, No 3, June, pp. 392-415

McDonald, I. and R. Solow (1982): Wage bargaining and employment, American Economic Review, 71, pp. 896-908.

Milgrom, P. and J. Roberts (1992): Economics, Organization, and Management, Prentice Hall, Englewood Cliffs, New Jersey

Pinto, B. and J. van Wijnbergen (1995): Ownership and corporate control in Poland. Why state firms defied the odds?, CEPR Discussion Paper No. 1273

Prasnikar, J., J. Svejnar, D. Mihalovic and V. Prasnikar (1994): Behaviour of participatory firms in Yugoslavia: lessens from transition economies, Review of Economics and Statistics Vol LXXVI. No. 4, 728-740 
Svejnar, J. (1982): On the theory of the participatory firm, Journal of Economic Theory,

\section{$27,313-330$}

\section{Appendix 1: Estimating the time lost for delays in the weaver's interventions}

The management observes three indicators of losses: $t^{\mathrm{S}}$ is the time lost for reasons outside the weaver's control such as maintenance, repair, lack of inputs, and so on. GROSS is the ratio of actual to potential output thus 1 -GROSS is the output lost during the breaks lasting for $t^{\mathrm{S}}+t^{\mathrm{W}}$ hours. ( $t^{\mathrm{W}}$ denotes the time until the looms are waiting for the weavers). NET is the output lost during $1-t^{\mathrm{S}}$ hours of operation. Denoting the potential product of a loom during a period with $q_{\mathrm{i}}$ and writing it in a mean-deviation form the following connections hold:

$$
\begin{aligned}
& N E T=\frac{\sum_{i=1}^{N}\left(1-t_{i}^{S}-t_{i}^{W}\right) \bar{q}+\sum_{i=1}^{N}\left(1-t_{i}^{S}-t_{i}^{W}\right)\left(q_{i}-\bar{q}\right)}{\sum_{i=1}^{N}\left(1-t_{i}^{S}\right) \bar{q}+\sum_{i=1}^{N}\left(1-t_{i}^{S}\right)\left(q_{i}-\bar{q}\right)} \approx 1-\frac{\bar{t}^{W}}{1-\bar{t}^{S}} \\
& \operatorname{GROSS}=\frac{\sum_{i=1}^{N}\left(1-t_{i}^{S}-t_{i}^{W}\right) \bar{q}+\sum_{i=1}^{N}\left(1-t_{i}^{S}-t_{i}^{W}\right)\left(q_{i}-\bar{q}\right)}{\sum_{i=1}^{N} q_{i}} \approx 1-\bar{t}^{S}-\bar{t}^{W} \approx\left(1-\bar{t}^{S}\right) \cdot N E T \\
& \text { if } \operatorname{Cov}\left(1-t_{i}^{S}, q_{i}-\bar{q}\right) \approx 0 \text { and } \operatorname{Cov}\left(1-t_{i}^{S}-t_{i}^{W}, q_{i}-\bar{q}\right) \approx 0
\end{aligned}
$$

Since NET, GROSS and $t^{\mathrm{S}}$ are observed by the management $t^{\mathrm{W}}$ can be easily calculated provided that the relative productivity of the looms and their time-waist are uncorrelated. The validity of this assumption can be checked by looking at the difference between GROSS and its estimate under the simplifying conditions discussed above $(\delta)$ :

$\delta=G R O S S-E s t(G R O S S)=G R O S S-\left(1-\bar{t}^{S}\right) \cdot N E T$ 
The data suggest that the interaction effects were indeed negligible with the exception of 1976 and 1991. The mean of $\delta$ was 0.003 in the 15 years for which observations were available. Therefore $t^{\mathrm{W}}=(1-N E T)\left(1-t^{\mathrm{S}}\right)=1-G R O S S-t^{\mathrm{S}}$ can be accepted as a measure of the time lost for delays in the weaver's intervention.

Table A1. Annual estimates and estimation errors of $\mathrm{t}^{\mathrm{W}}$

\begin{tabular}{cccccc} 
year & \multicolumn{1}{c}{ GROSS } & NET & $\mathrm{t}^{\mathrm{s}}$ & $\mathrm{t}^{\mathrm{w}}$ & \multicolumn{1}{c}{$\delta$} \\
1971 & 0.684 & 0.769 & 0.100 & 0.216 & -0.008 \\
1972 & 0.689 & 0.771 & 0.109 & 0.202 & 0.002 \\
1973 & 0.704 & 0.782 & 0.096 & 0.200 & -0.003 \\
1974 & 0.697 & 0.793 & 0.119 & 0.184 & -0.002 \\
1975 & 0.682 & 0.796 & 0.129 & 0.189 & -0.011 \\
1976 & 0.715 & 0.768 & 0.121 & 0.164 & 0.040 \\
1977 & 0.730 & 0.814 & 0.123 & 0.147 & 0.016 \\
1988 & 0.770 & 0.862 & 0.107 & 0.123 & 0.001 \\
1991 & 0.614 & 0.818 & 0.166 & 0.220 & -0.069 \\
1992 & 0.644 & 0.805 & 0.198 & 0.158 & -0.001 \\
1993 & 0.587 & 0.791 & 0.250 & 0.163 & -0.006 \\
1994 & 0.727 & 0.896 & 0.176 & 0.097 & -0.011 \\
1995 & 0.675 & 0.863 & 0.213 & 0.112 & -0.004 \\
1996 & 0.624 & 0.825 & 0.249 & 0.127 & 0.004 \\
1997 & 0.594 & 0.845 & 0.290 & 0.116 & -0.006 \\
\hline
\end{tabular}




\section{Appendix 2: Data sources and descriptive statistics}

Table A2: Data sources

\begin{tabular}{|c|c|c|c|}
\hline Variable & Frequency & Frequency & Unit of measurement, notes \\
\hline Number of looms & April 1991-July 1997 & Monthly & By types of looms \\
\hline Output & April 1991-July 1997 & Monthly & Weft-yarns, by types of looms \\
\hline Sales price of the plant & $1989-97$ & Annual & Price of the cloth sold on the market \\
\hline Number of workers & $1988-96$ & Annual & \\
\hline Working hours & $1988-96$ & Annual & Individuals \\
\hline Hours spent on sick leave & $1998-96$ & Annual & Individuals \\
\hline Wages & $1988-96$ & Annual & Individuals \\
\hline Alternative wage & $1989,1992-96$ & Annual & Individuals, Wage Survey \\
\hline Required effort (e*) & April 1991-July 1997 & Monthly & By types of looms \\
\hline GROSS, NET, $\mathrm{t}^{\mathrm{s}}, \mathrm{n}^{*}$ & April 1991-July 1997 & Monthly & By types of loomes \\
\hline
\end{tabular}

Table A2 : Selected variables of the weaving mill - Annual means

\begin{tabular}{lccc|cccccc|c}
\hline \multicolumn{1}{c}{ Years: } & 88 & 89 & 90 & 91 & 92 & 93 & 94 & 95 & 96 & 97 \\
\hline Owner (year-end) & State & For. & For. & Bank & Bank & Bank & Bank & Priv & Priv & \\
Output (weft-yarns) & 100 & 96.3 & 92.5 & 60.6 & 48.6 & 37.7 & 40.2 & 39.9 & 39.1 &.. \\
Number of looms & 100 & 91.1 & 82.3 & 73.4 & 48.3 & 36.1 & 32.8 & 32.8 & 32.9 & 35.1 \\
Full-capacity output & 100 & 99.8 & 99.5 & 76.0 & 58.1 & 49.4 & 42.6 & 45.6 & 48.2 &.. \\
Hours paid (weavers) & 100 & 103.8 & 113.4 & 113.6 & 74.2 & 53.3 & 45.2 & 38.4 & 40.2 &.. \\
Sales price of cloth &.. & 100 & 113.3 & 131.1 & 149.5 & 183.9 & 232.9 & 305.3 & 363.7 & 466.8 \\
- relative to textiles &.. & 100 & 97.0 & 86.0 & 88.0 & 98.2 & 112.7 & 115.6 & 115.4 &.. \\
- relative to manufactur. &.. & 100 & 92.8 & 81.0 & 82.2 & 91.3 & 103.9 & 105.6 & 102.5 & 108.1 \\
Real wage* & 100 & 92.6 & 86.8 & 82.4 & 72.3 & 81.0 & 84.4 & 76.4 & 68.2 &.. \\
Real wage cost** & 100 & 95.8 & 118.9 & 132.1 & 124.5 & 139.4 & 136.2 & 120.5 & 115.3 &.. \\
Relative wage*** & & & & & & & & & & \\
- national mean=100 & 100 & 99 & 81 & 83 & 77 & 79 & 70 & 74 & 68 &.. \\
- relevant market $=100$ & & 146 & & & 115 & 119 & 116 & 118 & 112 &.. \\
Capacity utilization & & & & & & & & & & \\
- gross & 100 & 93.2 & 86.4 & 79.7 & 83.6 & 76.2 & 94.4 & 87.6 & 81.0 & 77.1 \\
- net & 100 & 98.3 & 96.7 & 95.0 & 93.4 & 91.8 & 103.9 & 100.0 & 95.7 & 98.0 \\
- breaks $\left(\mathrm{t}^{\mathrm{S}}+\mathrm{t}^{\mathrm{W}}+\delta\right.$ ) & 100 & 118.3 & 136.8 & 155.1 & 185.0 & 233.6 & 164.1 & 199.4 & 232.6 & 271.2 \\
Interventions $/$ hour &.. &.. &.. & 100 & 103.9 & 104.0 & 96.0 & 88.5 & 106.6 & 111.9 \\
Union members $(\%)$ & 81.4 & 73.0 & 67.0 & 67.5 & 66.3 & 66.4 & 63.6 & 61.2 & 69.1 &.. \\
\hline
\end{tabular}

The plant-level figures relating to 1989 and 1990, if printed in italics, are interpolated using observed values from 1988 and January-May 1991. *) Average hourly wage deflated with the consumer price index.**) Average hourly wage deflated with the plant's sales prices ***) Average monthly wage of weavers employed on weekday shifts, throughout the year compared to the national average and the regional and occupational average as defined in the text. All figures were provided by the enterprise except nationwide and local wages which were taken from the Wage Survey, waves 1986, 1989 and 1992-96. 


\section{IZA Discussion Papers}

\begin{tabular}{|c|c|c|c|c|}
\hline No. & Author(s) & Title & Area & Date \\
\hline 957 & $\begin{array}{l}\text { M. Ebell } \\
\text { C. Haefke }\end{array}$ & $\begin{array}{l}\text { Product Market Deregulation and Labor Market } \\
\text { Outcomes }\end{array}$ & 6 & $12 / 03$ \\
\hline 958 & $\begin{array}{l}\text { T. Brück } \\
\text { J. P. Haisken-DeNew } \\
\text { K. F. Zimmermann }\end{array}$ & $\begin{array}{l}\text { Creating Low Skilled Jobs by Subsidizing } \\
\text { Market-Contracted Household Work }\end{array}$ & 5 & $12 / 03$ \\
\hline 959 & $\begin{array}{l}\text { T. Bauer } \\
\text { H. Bonin } \\
\text { U. Sunde }\end{array}$ & $\begin{array}{l}\text { Real and Nominal Wage Rigidities and the Rate } \\
\text { of Inflation: Evidence from West German Micro } \\
\text { Data }\end{array}$ & 1 & $12 / 03$ \\
\hline 960 & $\begin{array}{l}\text { A. Constant } \\
\text { K. F. Zimmermann }\end{array}$ & $\begin{array}{l}\text { Circular Movements and Time Away from the } \\
\text { Host Country }\end{array}$ & 1 & $12 / 03$ \\
\hline 961 & $\begin{array}{l}\text { C. N. Teulings } \\
\text { C. G. de Vries }\end{array}$ & $\begin{array}{l}\text { Generational Accounting, Solidarity and Pension } \\
\text { Losses }\end{array}$ & 3 & $12 / 03$ \\
\hline 962 & $\begin{array}{l}\text { L. Goerke } \\
\text { M. Pannenberg }\end{array}$ & $\begin{array}{l}\text { Norm-Based Trade Union Membership: } \\
\text { Evidence for Germany }\end{array}$ & 3 & $12 / 03$ \\
\hline 963 & $\begin{array}{l}\text { L. Diaz-Serrano } \\
\text { J. Hartog } \\
\text { H. S. Nielsen }\end{array}$ & $\begin{array}{l}\text { Compensating Wage Differentials for } \\
\text { Schooling Risk in Denmark }\end{array}$ & 5 & $12 / 03$ \\
\hline 964 & $\begin{array}{l}\text { R. Schettkat } \\
\text { L. Yocarini }\end{array}$ & $\begin{array}{l}\text { The Shift to Services: } \\
\text { A Review of the Literature }\end{array}$ & 5 & $12 / 03$ \\
\hline 965 & $\begin{array}{l}\text { M. Merz } \\
\text { E. Yashiv }\end{array}$ & Labor and the Market Value of the Firm & 1 & $12 / 03$ \\
\hline 966 & T. Palokangas & $\begin{array}{l}\text { Optimal Taxation with Capital Accumulation } \\
\text { and Wage Bargaining }\end{array}$ & 3 & $12 / 03$ \\
\hline 967 & $\begin{array}{l}\text { M. Lechner } \\
\text { R. Vazquez-Alvarez }\end{array}$ & $\begin{array}{l}\text { The Effect of Disability on Labour Market } \\
\text { Outcomes in Germany: Evidence from Matching }\end{array}$ & 6 & $12 / 03$ \\
\hline 968 & $\begin{array}{l}\text { M. Blázquez } \\
\text { M. Jansen }\end{array}$ & $\begin{array}{l}\text { Efficiency in a Matching Model with } \\
\text { Heterogeneous Agents: Too Many } \\
\text { Good or Bad Jobs? }\end{array}$ & 1 & $12 / 03$ \\
\hline 969 & $\begin{array}{l}\text { J.-P. Schraepler } \\
\text { G. G. Wagner }\end{array}$ & $\begin{array}{l}\text { Identification, Characteristics and Impact of } \\
\text { Faked Interviews in Surveys }\end{array}$ & 7 & $12 / 03$ \\
\hline 970 & $\begin{array}{l}\text { G. Kertesi } \\
\text { J. Köllõ }\end{array}$ & $\begin{array}{l}\text { Fighting "Low Equilibria" by Doubling the } \\
\text { Minimum Wage? Hungary's Experiment }\end{array}$ & 4 & $12 / 03$ \\
\hline 971 & $\begin{array}{l}\text { J. De Loecker } \\
\text { J. Konings }\end{array}$ & $\begin{array}{l}\text { Creative Destruction and Productivity Growth in } \\
\text { an Emerging Economy: Evidence from } \\
\text { Slovenian Manufacturing }\end{array}$ & 4 & $12 / 03$ \\
\hline 972 & J. Köllõ & $\begin{array}{l}\text { Transition on the Shop Floor - The Restructuring } \\
\text { of a Weaving Mill, Hungary 1988-97 }\end{array}$ & 4 & $12 / 03$ \\
\hline
\end{tabular}

An updated list of IZA Discussion Papers is available on the center's homepage www.iza.org. 